\title{
The diet of Scinax angrensis (Lutz) tadpoles in an area of the Atlantic Forest (Mangaratiba, Rio de Janeiro) (Amphibia, Anura, Hylidae)
}

\author{
Izidro F. de Sousa Filho; Christina C. Branco; Ana M. P. Telles de Carvalho-e-Silva; \\ Guilherme R. da Silva \& Leandro T. Sabagh
}

${ }^{1}$ Departamento de Zoologia, Universidade Federal do Estado do Rio de Janeiro. Avenida Pasteur 458, 22290-240 Rio de Janeiro, Rio de Janeiro,Brasil.E-mail: izidro@unirio.br, cbranco@unirio.br, atteles@unirio.br, grscinax@ig.com.br, sabagh@yahoo.com.br.

\begin{abstract}
Scinax angrensis (Lutz, 1973) is an endemic species, which occurs in low altitude hillside forests, distributed from the municipalities of Mangaratiba to Parati in the south of the state of Rio de Janeiro, Brazil. The aim of this study was to compare the morphology of S. angrensis tadpoles in two different stages of development, and verify their feeding spectrum. The mouth morphology of the two stages studied (27 and 37) appeared similar, with a difference in the size of the oral opening as well as an increase in the dimensions of the body. The examined species presented a trophic spectrum comprised of algae, protozoan, rotifers, microcrustaceans, nematodes, vegetation and invertebrate remains, fungus hyphae, and sand grains. Significant differences were found between dimensions of the two stages, but not between diets, although a differentiated preference with regards to planktonic items has been verified. The results suggest that the partitioning of feeding resources is not only related to morphology and occupation of different microhabitats but also to the feeding behaviour of tadpoles. The relevance of important food items to the natural diet of $S$. angrensis tadpoles, especially the diatoms and filamentous algae, reveal the importance of the periphytic community to the conservation of this species in the Atlantic Forest.
\end{abstract}

KEY WORDS. Amphibian; natural diet.

RESUMO. Dieta de girinos de Scinax angrensis (Lutz) na Floresta Atlântica (Mangaratiba, Rio dejaneiro) (Amphibia, Anura, Hylidae). Scinax angrensis (Lutz, 1973) é uma espécie endêmica ocorrendo em florestas de encosta de baixa altitude, no sul do Estado do Rio de Janeiro, Brasil. O objetivo do presente estudo foi o de comparar a morfologia e verificar o espectro alimentar de girinos de $S$. angrensis de dois estágios diferenciados de desenvolvimento. A morfologia bucal dos dois estágios (27 e 37) apresentou-se similar, havendo diferença de tamanho da abertura oral, bem como aumento das dimensões do corpo e da cauda. A espécie examinada apresentou um espectro trófico integrado por algas, protozoários, rotíferos, microcrustáceos, nematódeos, restos de vegetais e de invertebrados, hifas de fungo e grãos de areia. Foram verificadas diferenças significativas entre as dimensões dos dois estágios, embora não se tenha encontrado uma diferença significativa entre as dietas, apesar de se ter observado uma preferência diferenciada por itens planctônicos. Os resultados sugerem que a partilha de recursos alimentares está relacionada não só com a morfologia e ocupação de diferentes microhábitats, mas também ao comportamento alimentar dos girinos. A relevância de itens importantes para a dieta natural dos girinos de $S$. angrensis, especialmente as algas diatomáceas e filamentosas, revela a importância da comunidade perifítica para a conservação desta espécie de anuro na Mata Atlântica.

PALAVRAS-CHAVE. Anfíbios; dieta natural.

Amphibians are the most primitive vertebrates amongst the tetrapods, but they are also the most successful animals which still have larva and present free living embryos (IzECKSONH $\&$ CARVAlHo-E-Silva 2001). Of the three orders of amphibians, the larvae of anurans are the ones that differ the most from their adult form, being also the most specialized Duellman \& Trueb (1994). The morphological diversity of tadpoles is quite great, especially when one considers their short lifecycle (Attig $\&$ McDiarmid 1999). The variations in the diverse types of tadpole bodies are apparently correlated to their phylogeny and ecology.

In aquatic tropical ecosystems, the study of the natural diet of resident species is an important tool in understanding the biotic and abiotic interrelationships existing not only in the 
aquatic environment but also in the water-land ecotone, subsidizing therefore the management and environmental protection of these areas. On the other hand, specifically, the study of the feeding spectrum of aquatic vertebrates has reflected not only the availability of food in the environment, but also the choice of the most appropriate feeding item to fulfill nutritional necessities to metamorphosis such as in anurans (KupferberG 1997a) or ontogenetic differences as in fish (Aguiaro \& CARAMashi 1995). The analyses of the natural diet of a species indicates its role in the local trophic web, possibly revealing narrow links between communities and delineating the regulatory effect of the predator/grazer over its prey/primary producer. Further, this knowledge also indicates the susceptibility of the species in question in light of current environmental changes.

Tropical regions harbor a great richness of amphibian species due to specific characteristics of their habitats. The study of Kopp \& ETERovick (2006) on the factors influencing anuran assemblages in southeastern Brazil enhanced the importance of environmental and stochastic factors on the observed patterns of species distribution over biotic interactions. The availability of food and the strategies for it acquisition can also be considered important factors responsible for the spatial and temporal distribution of anuran populations in these areas. The destruction of tropical forests, especially remnants of Atlantic Forest, has the direct consequence of the disappearance of natural habitats, but also the erosion, and build-up of sediments, and the complete alteration of water quality of natural springs, streams, and rivers. These modifications alter completely the availability of food items used by larval and adult anurans, both in qualitative and quantitative terms.

Tadpole ecology is complex and reflects a majority of the processes that govern the dynamics of a population and community. The morphology of a tadpole's mouth makes it mainly a highly specialized filterer, capable of living in assemblages in diverse habitats since among species there is a diversity of mouth parts specialized in food capture. Generally, tadpoles are considered herbivorous filterers, but can ingest planktonic items, mosquito larva, organic sediments from the bottom of lakes and rivers, pollen, graze on the periphyton, leaves and animal remains in decomposition, and even consume amphibian eggs, other tadpoles, and benthic macroinvertebrates (DuelLman \& Treub 1994, Arias et al. 2002, Dutra \& Callisto 2005). Some authors have used the mouth and body morphology of tadpoles in diverse stages of development in order to suggest the type of food ingested by these individuals and their feeding behavior (Altig \& McDiarmid 1999). Besides these general considerations, studies on natural diets of tadpoles in tropical forests are still rare.

Scinax angrensis was described by LuTz (1973) and its larva was described by CarvalHo-e-Silva et al. (1995). According to these last authors it is considered a medium sized, endemic species occurring in low altitude hillside forests up to approximately $1300 \mathrm{~m}$, reproducing in perennial or temporary streamlets, as well as in small temporary clear small ponds as- sociated with brooks inside the forests and, more rarely in rocky pools, and distributed from the municipalities of Mangaratiba to Parati, in the Rio de Janeiro State.

The objective of the present study was to verify the feeding spectrum of the Scinax angrensis tadpole in two different stages of development. Our hypothesis is that the stages studied, due to morphological similarities, should explore similar food items in the aquatic environment.

\section{MATERIAL AND METHODS}

\section{Study area}

The Atlantic Forest borders the coast of Brazil, from the northeast to south, in the State of Rio Grande do Sul. The entire area is within the tropical zone and is marked by a maritime climate with high precipitation and humidity. This high precipitation in the southern of the Rio de Janeiro State is brought on by maritime winds which, encountering the Serra do Mar mountain range causes a steady occurrence of rain throughout the year together with elevated temperatures. These factors converge to create one of the most complex ecosystems in the world, with a large diversity of anurans. The Fazenda Goiabal, is a farm known more commonly as the Reserva Rio das Pedras (ReRP), a special class of private protected area called "Reserva Particular do Patrimônio Natural" (RPPN). The farm is located at km 55 on the BR 101 highway (Rio-Santos), in the Municipality of Mangaratiba, in the coordinates $22^{\circ} 59^{\prime} \mathrm{S}-44^{\circ} 05^{\prime} \mathrm{W}$. It encompasses an area of 1361 ha and has an altitude ranging from a maximum of $1150 \mathrm{~m}$ to a minimum of $20 \mathrm{~m}$. The region possesses a tropical hot and very humid climate with an average annual temperature of $22^{\circ} \mathrm{C}$ and an average annual rainfall of $1900 \mathrm{~mm}$, October and January being the rainiest months.

\section{Collection and preparation of samples}

The field work was undertaken 27-29 April of 2002, during the rainy season in the Rio Borboleta, ReRP, Municipality of Mangaratiba, State of Rio de Janeiro. We collected 60 larvae of $S$. angrensis from a permanent pool using a fine mesh net. The tadpoles were immediately fixed following collection, by direct immersion in 10\% formalin, in order to avoid the regurgitation of contents in the digestive tract. Afterwards, in the laboratory, a triage was conducted, separating individuals of the 27 and 37 stages according to Gosner system GOSNER (1960), which were subsequently preserved in 5\% formalin. Body and tail lengths, height, total body length, and mouth width were taken according to ALTIG \& MCDIARMID (1999) from individuals of both stages with a pachymeter.

In order to analysis diet, 15 individuals were randomly selected from both the 27 and 37 stages. All the digestive tracts of these individuals were removed, dried and homogenized in $1 \mathrm{ml}$ of distilled water, after which the material was placed in a Sedgewick-Rafter counting chamber and analyzed using an optical microscope. The food items were identified according to guides for the identification of algae (Bicudo \& Menezes 2005), 
protozoans (KUdo 1985, FOISSNER \& BERgER 1996) and invertebrates (Koste 1978, Thorp \& Covich 2001). For each feeding item, the numeric frequency ( $\% \mathrm{NF})$ and the frequency of occurrence (\%FO) were calculated with the percentage based on the number of total feeding items and the total number of digestive tracts analyzed. To evaluate the existence of significant differences between the dimensions of the two stages and their diets the nonparametric Mann-Whitney test (ZAR 1996) available in the software Statistica vers. 6.0 was used.

\section{RESULTS}

The tadpoles of $S$. angrensis were observed spending most of their time attached to some sort of substrate, below detritus, eventually swimming freely. They were found both in pools which are shaded and in direct sunlight. They do not appear to demonstrate a preferred time of day as they are found to be active both during the day as well as the night. Their color is quite similar to the substrate found at the bottom of these pools, making them harder to observe.

The average dimensions of the stages 27 and 37 of $S$. angrensis are found in table I. The stages 27 and 37 display a similar mouth structure, only differing in size. Among the morphological data measured in the two stages, the dimension of the mouth opening was the measurement that increased the most $(65 \%)$ from one stage to other. Although one measured $2.0 \mathrm{~mm}$ (stage 27) and the other $3.3 \mathrm{~mm}$ (stage 37), it could be argued that this relatively larger opening could facilitate the ingestion of larger sized microscope items.

Other morphological differences detected between the

Table I. Average value of the density of feeding items found in each individual for the stages 27 and 37 of S. angrensis.

\begin{tabular}{lcc}
\hline \multicolumn{1}{c}{ Items } & Stage $27(\mathrm{n}=15)$ & Stage $37(\mathrm{n}=15)$ \\
\hline Euglenophytes & 2.0 & 1.8 \\
Diatoms & 116.8 & 23.1 \\
Filamentous algae & 18.0 & 73.0 \\
Testaceans & 5.3 & 26.5 \\
Opalinids & 0.0 & 11.7 \\
Ciliates & 9.0 & 9.0 \\
Rotifers & 0.0 & 5.0 \\
Cladocerans & 0.0 & 2.6 \\
Nematodes & 26.1 & 45.4 \\
Invertebrate debris & 0.9 & 6.5 \\
Vegetation debris & 0.1 & 3.1 \\
Others & 0.8 & 8.5 \\
Sand grains & 38.3 & 23.5 \\
\hline
\end{tabular}

two stages were relative to tadpole body and tail size and the development of the posterior side of the body, with stage 27 containing only limb buds while in stage 37 individuals dis- played the presence of diminutive limbs. Coloration was also slightly different between both stages.

According to the Mann-Whitney test there was no significant difference between the dimensions obtained for the two stages $(U=9, P=0.464703)$. Despite of this result, from the 27 to the 37 stage, there was an increase of between 32 and $46 \%$ in the dimensions of the body and tail and a $65 \%$ increase in the opening of the mouth.

\section{Diet Analysis}

The examined species displayed a trophic spectrum made up of euglenophytes algae, diatoms mainly of the genera Achananthes, Navícula, Pinullaria, Tabellaria, Fragillaria, Diatoma, Surirella, Nitzschia, Meridion, filamentous algae (most chlorophytes), protozoan of the genus Opalina, testacean amoebae of the genera Difflugia, Centropyxis, Lesqueuresia, Arcella, Euglypha, unidentified ciliates, rotifers of the genera Platyas and Lecane, microcrustaceans from the cladoceran group, nematodes, vegetation debris, invertebrate debris, eggs of unidentified invertebrates, fungus hyphae, and sand grains. The 31 items were grouped into 13 categories (Tab. II). According to the MannWhitney test there was no significant difference was found between the diets of the two stages, with respect to the grouped items $(\mathrm{U}=47.50, \mathrm{P}=0.157214)$. Although, when analyzing separately the abundance of the genera of the algae and invertebrates, a significant difference in consumption was found between these two stages according to the same test for zooplankton $(\mathrm{U}=31.50, \mathrm{P}=0.000220)$ and phytoplankton $(\mathrm{U}=$ 38.00, $\mathrm{P}=0.049599)$.

For the stage 27 (Fig. 1) the most representative items in

Table II. Dimensions ( $\mathrm{mm}$ ) of the 27 and 37 stages of S. angrensis as well as the relative growth from one stage to the other.

\begin{tabular}{lccc}
\hline \multicolumn{1}{c}{ Parameters } & Stage 27 & Stage 37 & \% of increase \\
\hline Body length & 7.0 & 9.8 & 40 \\
Tail length & 11.7 & 16.3 & 39 \\
Tail height & 3.1 & 4.1 & 32 \\
Total body length & 18.5 & 27.1 & 46 \\
Mouth width & 2.0 & 3.3 & 65 \\
\hline
\end{tabular}

terms of frequency of occurrence were diatoms, filamentous algae, vegetation debris and sand grains with a $100 \%$ frequency of occurrence, followed by testaceans $(73.3 \%)$, ciliate protozoans and euglenophytes with $26.7 \%$. The items: rotifers, opalinids and cladocerans were not present. For the stage 37 the most representative items in terms of frequency of occurrence were sand grains, testaceans, opalinids and vegetation debris with a $100 \%$ frequency of occurrence, followed by nematodes and rotifers with 93.3\%; others (eggs and fungus hyphae), animal and diatoms remains with $86.7 \%$, cladocerans $(66.7 \%)$, protozoans and filamentous algae with $60.0 \%$. The least significant item was the euglenophytes with $33.3 \%$. 


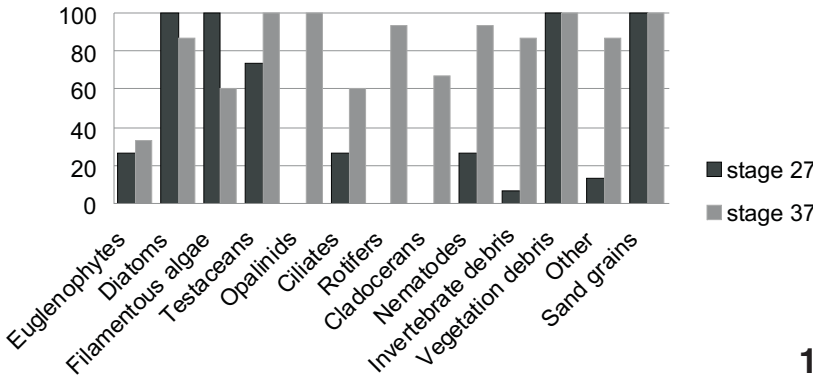

Figures 1-2. (1) Frequency of occurrence of items in the stages 27 and 37; (2) numeric frequency of items in the composition of the diet for stages 27 and 37.

For the stage 27 (Fig. 2) the most representative items in terms of numeric frequency were diatoms (53.8\%), vegetation debris $(17.6 \%)$, sand grains $(12.0 \%)$ and filamentous algae $(8.3 \%)$. For the stage 37 the most representative items in terms of numeric frequency were sand grains $(26.3 \%)$, testaceans (15.3\%), vegetation debris (13.6\%), diatoms (13.4\%), opalinids with $6.8 \%$ and other protozoans with $5.3 \%$.

\section{DISCUSSION}

Amphibian larvae may constitute an important link in the trophic web of fresh water environments, acting upon communities of periphytic, epilitic, and epibenthic algae and also removing suspended particles by filtration and apprehension strategies through the production of mucus (WASSERSUG 1972). In a general sense, anurans can also act as a link between the aquatic and terrestrial ecosystems, since the material consumed by the larvae in the aquatic habitat will be taken to the terrestrial environment by the adult. According to Seale \& BeckVar (1980) the ingestion of nitrogen-fixing algae by tadpole takes this element, by an exotic form, from the aquatic to the terrestrial food web.

Feeding in tadpoles is related to the type of mouth apparatus they have, availability of feeding items and even individual preferences with regards to microhabitat utilization, the latter associated as much with ontogenetic characteristics as inter-specific competition (Heyer 1976). The mouth apparatus of $S$. angrensis, with its innumerous tooth and keratinized jaw sheath is adapted for scraping its food from surfaces and fragmenting larger particles before ingesting them.

Ontogenetic differences in aquatic organisms can result in different behaviors in the water and, as a consequence, resulting individuals residing in distinct niches. A relative increase in tadpole body size from one stage to the next may imply a greater conspicuousness, as well as a greater swimming capacity which aids not only in exploration of other niches, escape from predators, but also in the increase of nutritional necessities. The former, capable of being enhanced during the following stages of metamorphose.

Since the stages 27 and 37 of $S$. angrensis show diets that do not appear to be different with respect to the main feeding item categories, the initial hypothesis of this study was corroborated. Besides this, upon further analysis of the major food items found between the two stages, a significant difference was observed between the genera of algae and invertebrates consumed by both stages. Although it is widely known that scraper tadpoles should have low selectivity with regards to the specificity of ingested items, some authors have already found such tadpoles feeding behavior selection in favor of conifer pollen (WAGNER 1986) and algae with a greater energetic value (KupFerberg 1997a).

The diet of $S$. angrensis in the stage 27 was based on diatoms, chlorophytes, and filamentous algae and vegetation debris. The nutritional variation within the algae routinely consumed by the tadpoles could influence metamorphose in several ways. According to Kupferberg (1997a), the natural diet of anuran larva can vary widely in terms of quantity of proteins, carbohydrates, and lipids, factors that influence the function of thyroid hormones, which are essential in order for metamorphosis to occur. In experimental situations, tadpoles fed with filamentous algae with epiphytic diatoms developed more rapidly and metamorphosed with larger body size than tadpoles submitted to a diet of commercially processed food (Kupferberg et al. 1994). Both filamentous algae as well as diatoms are considered important sources of nutrients since the periphytic community, where they occur in abundance, is well explored by the aquatic fauna both invertebrates and vertebrates. The importance of diatoms as a food source has also been seen in other anuran genera such as Lithobates, Dendropsophus, Eupemphix and other species of Scinax (HENDricks 1973, Kupferberg 1997b, Rossa-Feres et al. 2004). Diatoms can be richer in calories, mainly as a form of lipids, than the clorophytes and they are more easily accessible for consumption than filamentous algae (Kupferberg et al. 1994). It is worth to note that the clorophyte algae store the products of photosynthesis as a form of carbohydrates (Bold \& Wynne 1985), which is also an important food resource.

The pronounced presence of vegetation debris in the tadpole diet indicated that tadpoles in the stage 27 and 37 fed actively by scraping the surface of aquatic macrophytes. These results are in accordance with the behavior of $S$. angrensis tad- 
poles as described by CARVALHO-E-SILVA et al. (1995) who observed that tadpoles remained attached to the substrate, scraping it in order to feed, eventually, going to the surface. This habit of scraping and consuming periphyton could explain the presence of testaceans and ciliates commonly found in the periphytic community (Kudo 1985, Bérzins \& STENSDOTTER 1990) in the tadpoles' diet.

Many benthic tadpoles feed on debris and organisms found in the sediment in addition to the periphyton (KUPFERBERG 1997b, Altig \& McDiarmid 1999), which can result in the accidental presence of sand grains, as was found in both 27 and 37 stages. On the other hand, it can be supposed that the ingestion of sand grains could be a more active process done in order to take advantage of the bacterial film present on the grains or even in order to aid in the breakdown of vegetation cells in the digestive tract.

Nematodes, the other food item common in tadpoles of both stages, were found with the greatest frequency and abundance in the stage 37 . Nematodes were also observed in the digestive tract of a majority of the 17 species of anurans studied by Heyer (1973) in diverse tropical aquatic habitats in Thailand. Although this author did not distinguish between freeliving or parasitic nematodes by way of their abundance and/ or behavior in the intestinal tract, he did consider most to be parasitic, determining that those nematodes that numbered 1 to 4 individuals per intestine had been ingested. The densities of nematodes encountered in the present study, for both stages, suggest the existence of parasitism.

Comparing the natural diet of the two stages of $S$. angrensis, it was observed that the feeding of the stage 37 changed as much in numeric frequency as in the number of different items encountered, in comparison with that for the stage 27. However, in general terms, both stages presented greater abundances of the same feeding categories (diatoms, filamentous algae, testaceans, ciliates, nematodes, and sand grains), which resulted in no significant statistical difference between the diets when tested with a Mann-Whitney test.

Because of the greater frequency of occurrence of a higher number of feeding items observed in the stage 37, we concluded that this stage has a wider feeding spectrum. Since the only ontogenetic difference found between the oral morphology of the two stages was restricted to the size of the mouth opening, it is probably not responsible for the differences found between their diets, with the exception of different sizes of ingested food.

Tadpoles in the stage 37 reduced numerically their consumption of diatoms, filamentous algae, and vegetation while increasing their intake of zooplankton (rotifers and cladocerans) and other invertebrates, which could be a strategy to increase the amount of protein ingested. It should be pointed out that the larger mouth opening in the stage 37 allows for the entrance of larger items into the digestive tract, items such as cladoceran, predisposing individuals at this stage towards a diet richer in proteins.
According to KupFerberg (1997a), the tadpole development and metamorphosis could be limited by the protein content of their diet. STEINWACHSER \& Travis (1983) observed that growth and development of tadpoles of the species Hyla chrysoscelis Cope, 1880 was proportional to the protein/carbohydrate rate in their diet while NATHAN \& JAMES (1972) observed that the addition of protozoan to a diet of cooked lettuce decreased the metamorphosis time of tadpoles of the Chaunus (Wagler, 1828) genus.

Zooplankton items were also verified in tadpole diets from the species Scinax fuscovarius (Lutz, 1925), S. similis (Cochran, 1925), and S. fuscomarginatus (Lutz, 1925) (Rossa-Feres et al. 2004) and Scinax machadoi (Bokermann \& Sazima, 1973) (DUTRA \& Callisto 2005). According to the first authors, the presence of ciliates as well as other soft-bodied animals, such as testacean amoebae and rotifers could be an important finding, because they could be a valid source of nutrients for tadpoles. The difficulty in distinguishing such items inside the digestive tract and the presence of already digested material in the analysis has resulted in a lack of understanding the role these organisms play in the natural diet of tadpoles.

The increase in zooplankton predation by tadpoles of stage 27 to the 37 reveals also a different swimming behavior between the two stages, inferring, as observed in the field, a visit to the water surface in the latter. Morphological differences between the two stages such as the increase in tail length and height may allow different locomotion strategies in the water as well as more agility in movements, contributing to the access of a greater number of food items and corroborating the occurrence of more kinds of feeding items in the stage 37 . In addition, the slightly darker coloration of the stage 27 would allow a better protection against the dark bottom, while the lack of light lunulas in the stage 37 would make these individuals less conspicuous in the water. As found by Warkentin (1992) and Rossa-Feres et al. (2004), these results demonstrate that the partitioning of feeding resources is related not only to the occupation of diverse microhabitats, but also the feeding behavior of tadpoles.

Another difference between the feeding items of the two stages studied was in relation to the protozoan of the genus Opalina. The species of this genus are endocommensal that live inside the cloacal area of amphibians, but primarily in frogs and toads (KuDo 1985). Opalinids colonize the intestinal tract of tadpoles by way of cysts produced by adult anurans that are released into the surrounding water which are subsequently ingested by larvae. Opalins were not found in individuals in the stage 27 , while individuals in the stage 37 already possessed these protozoans in their digestive tracts.

Summarizing, similar to other young forms of anurans, tadpoles of $S$. angrensis show themselves to be herbivores, although the stage 37 can be considered as omnivorous due to the frequency of occurrence of items with animal origin. In a general sense, the young forms of $S$. angrensis can actively have an influence on the microhabitat in which they live, grazing and controlling the periphytic community, transforming algal

Revista Brasileira de Zoologia 24 (4): 965-970, dezembro 2007 
content, cycling nutrients, and also competing for food with other communities, such as aquatic insects.

The relevance of some food items to the natural diet of tadpoles of $S$. angrensis, especially the diatoms and filamentous chlorophytes, reveals the importance of the periphytic community for the feeding of this species of anuran. The endemism of $S$. angrensis means that alterations in the amount of sediments and nutrients, as well as decrease of streams flow in the area of its occurrence that may change the composition and biomass of periphyton, surely will impair the success of the tadpoles, the ending of metamorphose and the continued success of the species at this location.

\section{REFERENCES}

Aguiaro, T. \& E.P. Caramaschi. 1995. Ichtyofauna composition of three coastal lagoons in the north of the State of Rio de Janeiro (Brazil). Arquivos de Biologia e Tecnologia 38 (4): 1181-1189.

Altig, R. \& R.W. McDiarmid. 1999. Tadpoles the biology of anuram larvae. London, The University Chicago Press, IV+ $444 \mathrm{p}$.

Arias, M.M.; P.M. Peltzer \& R.C. Lajmanovich. 2002. Diet of the giant tadpoles Pseudis paradoxa platensis (Anura, Pseudidae) from Argentina. Phyllomedusa 1 (2): 97-100.

Bérzins, B. \& U. Stensdotter. 1990. Ecological studies of freshwater rhizopods. Hydrobiologia 202 (1-2): 1-11.

Bicudo, C.E.M. \& M. Menezes. 2005. Gêneros de algas de algas continentais do Brasil. São Carlos, Rima Editores, 508p.

Bold, H.C. \& M.J. Wynne. 1985. Introduction to the Algae: structure and reproduction. New Jersey, Prentice-Hall, VIII+720p.

Carvalho-e-Silva, S.P.; M.R. Gomes \& O.L. Peixoto. 1995. Descrição dos girinos de Scinax angrensis (B. Lutz, 1973) e de Scinax kautskyi (Carvalho e Silva \& Peixoto, 1991) (Amphibia, Anura, Hylidae). Revista Brasileira de Biologia 55 (1): 61-65.

Duellman, W.E. \& L. Trueb 1994. Biology of amphibians. London, John Hopkins, I+670p.

Dutra, S.L. \& M. Callisto. 2005. Macroinvertebrates as tadpole food: importance and body size relationships. Revista Brasileira de Zoologia 22 (4): 923-927.

Foissner, W. \& H. Berger 1996. A user-friendly guide to the ciliates (Protozoa Ciliophora) commonly used by hydrobiologists as bioindicators in rivers, lakes, and waste waters, with notes on their ecology. Freshwater Biology 35: 375-482.

GosNer, K.L. 1960. A simplified table for staging anuran embryos and larvae with note on identification. Herpetologica 16 (2): 183-190.

HendRICKS, F.S. 1973. Intestinal contents of Rana pipiens Schreber (Ranidae) larvae. Southwestern Naturalist 18: 99-101.
Heyer, W.R. 1973. Ecological interactions of frog larvae at a seasonal tropical location in Thailand. Journal of Herpetology 7 (4): 337-361.

Heyer, W.R. 1976. Studies in larval amphibian habitat partioning. Smithsonian Contr. Zoology 242: 1-27.

Izecksonh, E. \& S.P. Carvalho e Silva. 2001. Anfíbios do Município do Rio de Janeiro. Rio de Janeiro, Editora UFRJ, 147p.

Kopp, K.P. \& P.C. Eтerovick. 2006. Factors influencing spatial and temporal structure of frog assemblages at ponds in southeastern Brazil. Journal of Natural History 40 (29): 1813-1830.

Koste, W. 1978. Die Rädertiere Mitteleuropas (Monogononta) Bestimmungswerk Begründet von Max Voigt. Stuttgart, Gebruder Borntraeger, vol. 1, 673p, vol. 2, 474p.

Kudo, R.R. 1985. Protozoologia. México, Companhia Editorial Continental, 905p.

Kupferberg, S.J. 1997a. The role of larval diet in anuran metamorphosis. American Zoology 37 (2): 146-159.

Kupferberg, S.J. 1997b. Facilitation of periphyton production by tadpole grazing: functional differences between species. Freshwater Biology 37: 427-439.

Kupferberg, S.J.; J.C. Marks \& M.E. Power. 1994. Effects of variation in natural algal and detrital diets on larval anuran (Hyla regilla) life-history traits. Copeia (2): 446-457.

Lutz, B. 1973. New Brazilian forms of Hyla. I. Two new races of H. catharinae. Boletim do Museu Nacional 288: 1-7.

Nathan, J.M. \& V.G. James. 1972. The role of protozoa in the nutrition of tadpoles. Copeia (4): 669-679.

Rossa-Feres, D.C.; J. Jim \& M.G. FonseCa. 2004. Diets of tadpoles from a temporary pond in southeastern Brazil (Amphibia, Anura). Revista Brasileira de Zoologia 21 (4): 745-754.

Seale, D.B. \& N. Beckvar. 1980. The comparative ability of Anuran larvae (Genera: Hyla, Bufo and Rana) to ingest suspended blue-green algae. Copeia (3): 495-503.

Steinwachser, K. \& J. Travis. 1983. Influence of food quality and quantity on early growth of two anurans. Animal Behavior 48: 465-468.

ThorP, J.H. \& A.P. Covich. 2001. Ecology and classification of North American freshwater Invertebrates. San Diego, Academic Press, XVI+1056p.

Wagner, W.E. 1986. Tadpoles and pollen: observations on the feeding behavior of Hyla regilla larvae. Copeia (3): 802-804.

Warkentin, K.M. 1992. Microhabitat use and feeding rate variation in green frog tadpoles (Rana clamitans). Copeia (3): 731-740.

WASSERSUG, R. 1972. The mechanism of ultraplanktonic entrapment in anuran larvae. Journal Morphology 137: 279-288.

ZAR, J.H. 1996. Biostatistical analysis. New Jersey, Prentice Hall, $662 p$.

Received in 08.XI.2006; accepted in 14.XI.2007. 